\title{
Adult-onset vitelliform macular dystrophy: case report
}

\section{Distrofia macular viteliforme do adulto: relato de Caso}

Ricardo Evangelista Marrocos de Aragão․․ Ieda Maria Alexandre Barreira ${ }^{2}$. Gustavo Jose Arruda Mendes Carneiro $^{3}$. Nayara Queiroz Cardoso Pinto ${ }^{3}$. Talles Peterson Cavalcante Oriá ${ }^{3}$. Jhonatan de Paula Araujo Ferreira $^{3}$. Pedro Marques de Mesquita Filho ${ }^{3}$.

1 Doutor em medicina pela Universidade de Regensburg, Ratisbona, Alemanha, Preceptor de Retina do Hospital Universitário Walter Cantídio (HUWC), Professor voluntario de oftalmologia da Universidade Federal do Ceará (UFC), Fortaleza, Ceará, Brasil. 2 Oftalmologista do Centro Integrado de Diabetes e Hipertensão, Fortaleza, Ceará, Brasil. 3 Médico, residente de Oftalmologia, Hospital Universitário Walter Cantídio (HUWC), Fortaleza, Ceará, Brasil.

\section{ABSTRACT}

Adult-onset foveomacular vitelliform dystrophy is a rare disease. It shares heritance features with Best disease. Its onset is in the 3 rd and 5th decade, and it is characterized by subretinal deposition of yellowish material in the foveal area. Visual acuity ranges from 20/25 to 20/50, which can be seen in routine examination. Patient remains with good visual function throughout theirs lives. Typically the electro-oculogram may be normal or subnormal. We present a case of adult-onset vitelliform macular dystrophy, diagnosed in a patient with complaint of bilateral blurred vision.

Keywords: Macula lutea. Retina. Macula degeneration. Vitelliform macular dystrophy. Vision disorders.

\section{RESUMO}

Distrofia foveomacular viteliforme do adulto é uma patologia rara com as mesmas características hereditárias da doença de Best. Inicia-se na terceira ou quinta década de vida e caracteriza-se por depósitos subretiniano de material amarelado na área foveal. Acuidade visual varia de 20/25 a 20/50 e pode ser vista em um exame de rotina. Paciente costuma manter boa visão durante sua vida. O eletro-oculograma é tipicamente normal ou subnormal. Relatamos um caso de viteliforme do adulto em uma paciente com queixas de baixa de acuidade visual em ambos os olhos.

Palavras-chave: Macula lutea. Retina. Degeneração macular. Distrofia macular viteliforme. Transtornos da visão.

Corresponding Author: Ricardo Evangelista Marrocos de Aragão, Rua Osvaldo Cruz, 2335, Dionísio Torres, Fortaleza, Ceará. CEP: $60125-151$. Telefone: +55 85 9137-9313. E-mail: ricardomarrocos@yahoo.com

Conflict of interests: The authors have no conflicts of interest to declare.

Received: 29 Set 2016; Revised: 20 Jan 2017; Accepted: 20 Jan 2017. 


\section{INTRODUCTION}

Adult-onset foveomacular vitelliform dystrophy (AFVD) is a relatively uncommon macular disease, also known as pseudobest, pseudo-vitelliform, or Gass disease, is one of the pattern dystrophies. ${ }^{1,2}$ They share phenotypic features with Best vitelliform macular dystrophy (VMD), which may be inherited in a autossomal-dominant fashion with incomplete penetrance and with expression highly variable..$^{3,4}$ The onset is between 30 and 50 years with subretinal deposition of yellowish material within the macula. Visual acuity at onset ranges from 20/25 to $20 / 50$. The AFVD is pleomorphic and clinically heterogeneous disease, varying in the size, shape, distribution of the lesions, and pigmentary changes. ${ }^{3}$ The main complains, at the onset, are relative scotoma and metamorphosia, or it can be seen at routine examination. It may be misdiagnosed as Best disease or even as age-related macular degeneration. Eventually, the lesions may fade, leaving an area of retinal pigment ephitelium (RPE) atrophy. Most patients retains reading vision in at least one eye during their lives. The electro-oculogram (EOG) may be normal or only mildly subnormal.

\section{CASE REPORT}

A 41 year old, white female with complaint of longstanding bilateral blurred vision was referred for ophthalmology examination. Visual acuity with best corrected visual acuity was 20/50 in the right eye (OD), and 20/30 in the left eye (OS). Slit lamp examination was unremarkable, intraocular pressure was $10 \mathrm{mmHg}$ in both eyes. Binocular indirect ophthalmoscopy and retinal biomicroscopy revealed, in the OD, pigment atrophy in the fovea, and in the OS, a yellowish subretinal lesion in foveal region (Figure 1). Full-field electroretinography (ERG) was normal, EOG was subnormal with an Arden index of 1,5 in the OD and 1,3 in the OE (Figure 2).

Optical coherence tomography (OCT) in the OD revealed a difuse loss of the outer retina layers with atrophy, in the OS showed a hyporeflective top layer (likely to be fluid) and a hyper-reflective bottom layer (likely to be more proteinaceous material) that are sharply demarcated characterized the pseudohypopyon stage (Figure 3).

\section{DISCUSSION}

Adult foveomacular vitelliform dystrophy is usually presents bilaterally but unilateral has also been seen, as well as bilateral form after unilateral onset. ${ }^{5}$ Is a clinically heterogenous and pleomorphic disease, in which ophthalmoscopically changes often do not correspond with the visual function ${ }^{3}$ AFVD may be visually asymptomatic or mild visual blurring and metamorphopsia in one or both eyes. Usually the onset is between 30 and 50 years. Symmectric or even asymmetric solitary lesions, round, slightly elevated with yellow subretinal lesions is seen in the foveal region. ${ }^{6}$ It may show an extreme variability in the size, shape, and distribution of the yellowish material. ${ }^{1}$ The lesions may be larger as sometimes misdiagnosed as Best-disease or even as age-related macular degeneration. Eventually the lesion may fade, leaving an area of RPE atrophy, but most patients keep good vision in at least one eye throughout their lives. The EOG in these patients tends to be normal or only mildly subnormal. The features of optical coherence tomography (OCT) in the AFDV may show a homogeneous subretinal material, hyperreflective appearance. In atrophy stages exhibits central atrophy, pigmentary clumping, and subretinal fibrosis as well. ${ }^{7}$

No treatment is available except for the secondary choroidal neovascularization.

Figure 1. Retinography and autofluorescence showing in the OD pigment atrophy in the fovea, and in the OS, a yellowish subretinal lesion in foveal region.
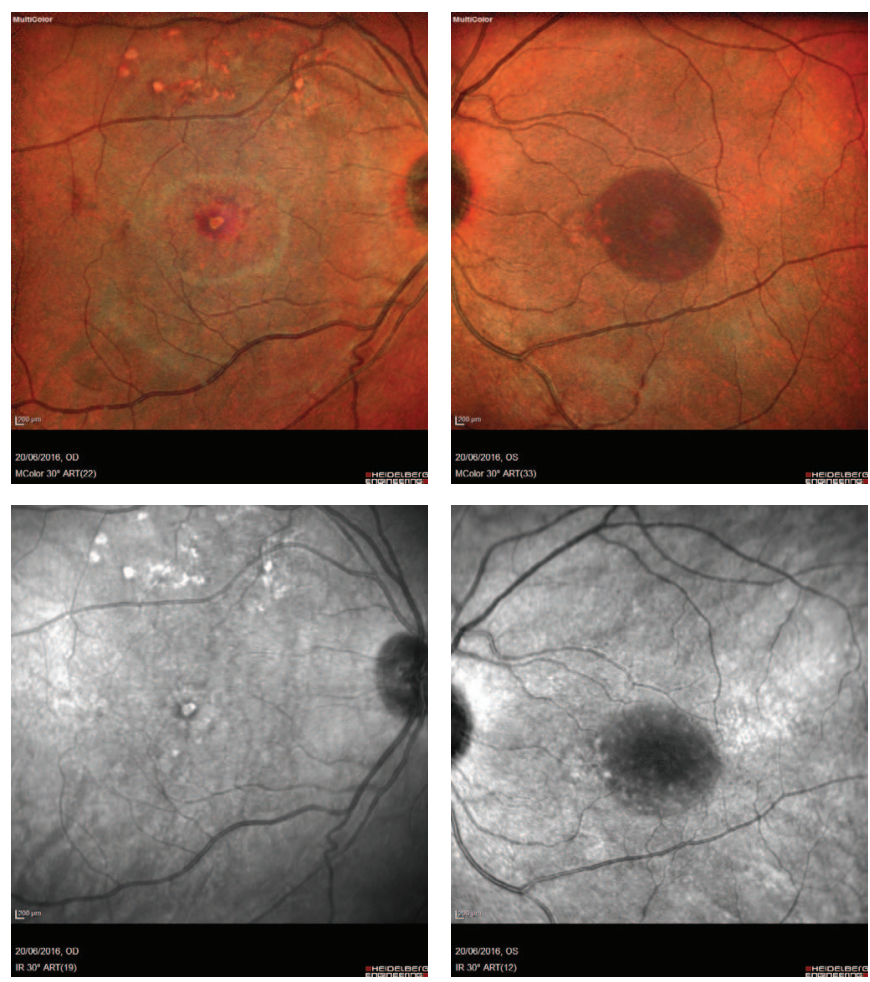

Figure 2. Full-field ERG was normal, EOG was subnormal with an Arden index of 1,5 in the OD and 1,3 in the OE.
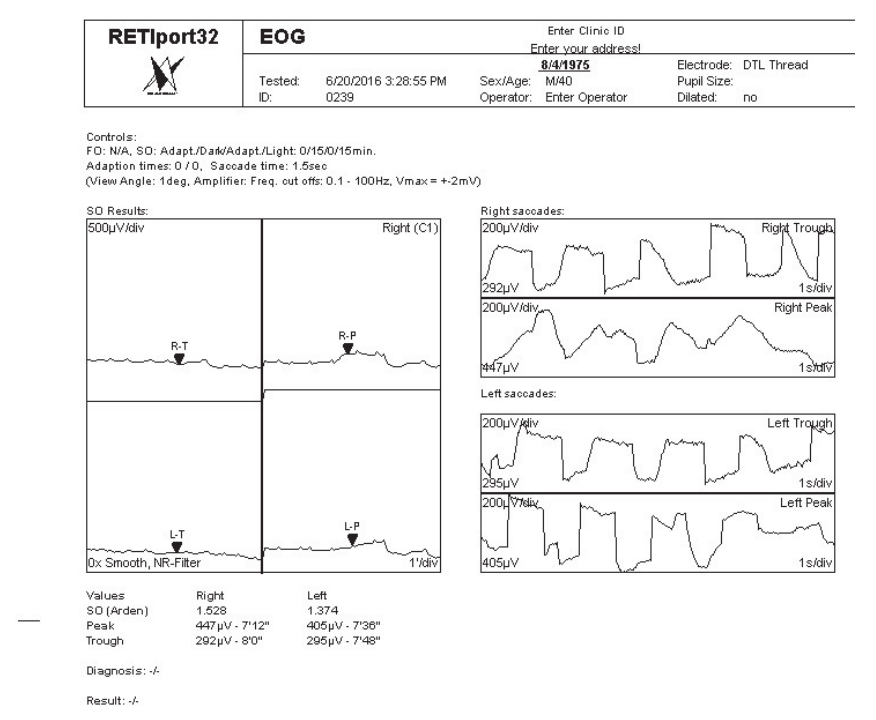
Figure 3. OCT in the OD revealed a difuse loss of the outer retina layers with atrophy, in the OS showed a hyporeflective top layer (likely to be fluid) and a hyper-reflective bottom layer (likely to be more proteinaceous material) that are sharply demarcated characterized the pseudohypopyon stage.
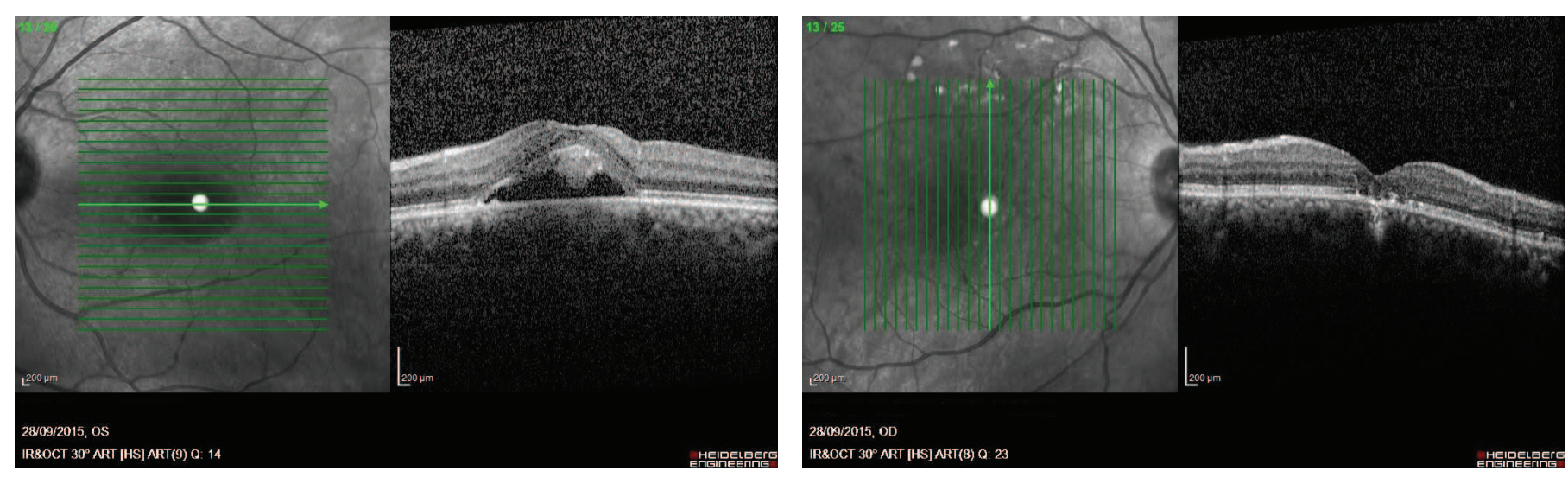

\section{REFERENCES}

1. Querques G, Forte R, Querques L, Massamba N, Souied E. Natural course of adult onset foveomacular vitelliform dystrophy. Invest Ophthalmol Vis Sci. 2011;52(14):2204.

2. Skuta GL, Cantor LB, Weiss JS. Basic and clinical science course [Internet]. San Francisco: American Academy of Ophthalmology; 2012 [Cited 2012 Dez 12]. Section 12, Hereditary retinal and Choroudal Dystrophies. Available from: http://www.aao.org

3. Querques G, Bux AV, Prato R, Iaculli C, Souied EH, Delle Noci N. Correlation of visual function impairment and optical coherence tomography findings in patients with adult-onset foveomacular vitelliform macular dystrophy. Am J Ophthalmol. 2008;146(1):135-42.

4. Yannuzzi LA. The retinal atlas. Elsevier Limited: [S. 1.]; 2010. Chapter 2, Macular Dystrophies; p. 50-7.

5. Balarin V, Lira RP, Berezowsky M, TorigoeAM. Adult foveomacular vitelliform dystrophy. Rev Bras Oftalmol. 2013;72(3):197-199.

6. Agarwal A. Gass' Atlas of macular diseases. 5. ed. Elsevier: [S. 1.]; 2012. Chapter 5, Autossomal-Recessive Bestrophinopathy; p. 250-60.

7. Chen KC, Jung JJ, Curcio CA, Balaratnasingam C, Gallego-Pinazo $\mathrm{R}$, Dolz-Marco R, et al. Intraretinal hyperreflective foci in acquired vitelliform lesions of the macula: clinical and histologic study. Am J Ophthalmol. 2016;164:89-98.

\section{Como citar:}

Aragão RE, Barreira IM, Carneiro GJ, Pinto NQ, Oriá TP, Ferreira JP, et al. Adult-onset vitelliform macular dystrophy: case Report. Rev Med UFC. 2018 jan-mar;58(1):62-64. 